\title{
PENGAJARAN MIKRO Suatu Pendekatan Menuju Guru Profesional
}

\author{
Oleh: Nurlaila*
}

\begin{abstract}
Microteaching plays very important roles in preparing (candidate) teachers to become professional since through practices on microteaching approach, basic teaching skills can be fully understood and practiced by the candidate teachers. Consequently, the teachers can achieve the effectiveness of teaching, that is, the accomplishment of goals and satisfactory learning outcomes.
\end{abstract}

Kata kunci: pengajaran mikro, keterampilan dasar mengajar, guru profesional

\section{PENDAHULUAN}

$\mathrm{P}$ ersiapan materi yang bersifat teoritis penting artinya dalam mempersiapkan calon guru, namun latihan praktis tidak kalah pentingnya dari semua teori itu. Praktek Pengalaman Lapangan (PPL) di sekolah-sekolah merupakan media terbaik untuk melatih calon guru dalam mengajar dan melatih kemampuan mereka dalam menguasai keterampilan-keterampilan mengajar tersebut sebelum terjun ke lapangan pendidikan yang sesungguhnya dimana mereka sudah jauh dari bimbingan, arahan dan pantauan pembimbing.

Berlatih mengajar di kelas dengan peserta didik 40 orang dan alokasi waktu 40 menit dalam satu pertemuan merupakan pekerjaan yang tidak mudah bagi seorang calon guru yang sedang berlatih (praktikan), perhatiannya sering tertuju pada peserta didik yang sedang belajar sehingga terabaikan tujuan utamanya bahwa dia sedang belajar mengajar. Bahkan jika praktikan mengalami kekeliruan mengajar akan berakibat langsung pada sekian banyak peserta didik. Untuk melengkapi kekurangan tersebut, di- kembangkan pengajaran mikro (micro teaching) guna menunjang Praktek Pengalaman Lapangan (PPL), artinya sebelum calon guru dikirim ke sekolahsekolah untuk mengikuti Praktek Pengalaman Lapangan (PPL) mereka terlebih dahulu dilatih melaksanakan pengajaran mikro (micro teaching).

Dalam pengajaran mikro, calon guru (praktikan) dilatih untuk menguasai sejumlah keterampilan, melakukan berbagai bentuk langkah dan kegiatan, yang dilanjutkan dengan diskusi tentang masalah-masalah yang dihadapi, dengan menggunakan rekaman video, dihadiri dosen pembimbing, dan saling bertukar peran antara praktikan. Bagaimana konsep pengajaran mikro, apa latar belakang historis dan teoritis yang mendasarinya, keterampilan mengajar apa saja yang dilatihkan dalam pengajaran mikro, apa saja macam-macamnya dan apa manfaatnya?

\section{KONSEP PENGAJARAN MIKRO}

Micro teaching berasal dari dua kata yaitu micro berarti kecil, terbatas,

* Penulis adalah Asisten Ahli dalam Mata Kuliah Bahasa Arab pada STAIN Batusangkar 
sempit dan teaching berarti mengajar. Jadi, micro teaching berarti suatu kegiatan mengajar yang dilakukan dengan cara menyederhanakan atau mengecilkan seluruh aspek yang ada dalam pembelajaran, seperti jumlah murid, waktu, bahan mengajar dan membatasi keterampilan mengajar tertentu. Dengan micro teaching ini akan dapat diidentifikasi berbagai keunggulan dan kelemahan pada diri calon guru secara akurat. Dalam bahasa Indonesia disebut dengan pengajaran mikro.

Pengajaran mikro merupakan suatu pendekatan dalam pengajaran, dimana guru berlatih melaksanakan proses pembelajaran yang sebenarnya dengan dimikrokan menyerupai ruangan kelas sebagaimana biasanya, dan mencakup seluruh aspek yang mesti ada dalam proses pembelajaran sebagaimana biasanya. Dalam kelas kecil itu, agar mendalam biasanya guru hanya melatihkan satu atau dua keterampilan mengajar, sebelum masuk pada keterampilan yang baru (al-Fara, 1999). Mc. Laughlin dan Moulton (1975:9) menyatakan micro teaching is as performance training method designed to isolate the component parts of the teaching process, so that the traince can master each component one by one in a simplifield teaching situation.

Pengajaran mikro dilakukan dengan melatih calon guru dalam mengajarkan sebagian dari beberapa bagian materi pelajaran atau suatu keterampilan dari beberapa keterampilan dengan batas-batas yang telah ditentukan, dan biasanya juga memberikan batasanbatasan bagi siswanya yang terdiri dari rekan-rekan calon guru yang berlatih tersebut. Calon guru yang berlatih (praktikan) harus memperhatikan aspek waktu serta kegiatan-kegiatan yang mesti ada dalam situasi sebagaimana pengajaran biasanya sehingga praktikan tersebut harus fokus untuk berlatih membuka pelajaran saja atau menjelaskan pelajaran, memberikan latihan, mengevaluasi kemampuan siswa dalam materi tertentu, memberikan pertanyaan, membetulkan kesalahan dan lain sebagainya. Praktikan bisa melaksanakan kegiatan ini satu kali, dua kali atau lebih sampai betul-betul menguasai keterampilan yang dilatihkan.

Berlatih salah satu keterampilan dari beberapa keterampilan tidak boleh menghabiskan semua waktu yang disediakan untuk pelajaran, melainkan harus sebagian saja sesuai dengan karakteristik keterampilan yang dilatihkan. Membuka pelajaran misalnya, biasanya tidak lebih dari lima menit, memberikan satu latihan mungkin tidak lebih dari tiga menit, menimbulkan rasa ingin tahu siswa atau memberikan pertanyaan atau menjawab pertanyaan tidak lebih dari satu menit, sedangkan menjelaskan materi sekitar lima sampai sepuluh menit. Di samping itu, Cassel (1988: 5) menjelaskan bahwa kelas harus dimikrokan sehingga lebih kecil dari sepuluh orang, dan mereka ini terkadang adalah siswa yang sebenarnya sedang belajar suatu materi, atau terkadang teman-teman dari guru yang sedang berlatih yang duduk di bangku belajar, mendengarkannya, berinteraksi dengannya sebagaimana layaknya mereka adalah siswa yang sebenarnya yang sedang belajar suatu materi pelajaran. Dan hal yang kedua inilah yang sering diikuti dalam pengajaran mikro dalam program pembelajaran.

Pada pengajaran biasa di kelas semua komponen keterampilan mengajar dilakukan oleh (calon) guru secara terintegrasi. Sedangkan pada pengajaran mikro, calon guru hanya melakukan 1-2 komponen keterampilan saja, secara terisolasi. Setelah calon guru menguasai beberapa keterampilan, maka ia mulai berlatih melakukan beberapa komponen keterampilan sekaligus secara terintegrasi, misalnya menggunakan penguatan waktu memberikan pertanyaan. Pemberian waktu disesuaikan dengan komponen yang dilatihkan. 
Berdasarkan konsep di atas, dapat dipahami bahwa pengajaran mikro itu tetap sebagai "real teaching" tetapi dengan memikrokan hampir semua komponen dalam pengajaran berupa jumlah murid, bahan pengajaran, waktu, jenis ketrampilan mengajar yang digunakan dan lain-lain. Dengan demikian kegitan pengajaran tersebut menjadi mudah dikontrol dan mudah diidentifikasi keunggulan dan kelemahannya.

\section{LATAR BELAKANG HISTORIS DAN TEORITIS PENGAJARAN MIKRO}

Pengajaran mikro muncul pada awal tahun 1960-an, ketika adanya penerapan pendekatan behaviorisme dalam psikologi (behavioral psychology) yang menguasai sistem pembelajaran. Pengajaran mikro dalam ilmu-ilmu terapan mulai mulai dilaksnakan di Stanford University oleh Dwight Allen dan teman-temannya pada tahun 1961 yang dikenal dengan pendekatan Stanford (Stanford approach), kemudian juga dilekasanakan di University of California (Barkeley). Pada waktu itu model pengajaran ini dikenal dengan The Applied Science Model, kemudian setelah itu dilaksanakan dalam lapangan yang lebih luas dalam melatih para arsitek dan pekerja di pabrik-pabrik dan dalam program latihan tentara Amerika.

Sejak saat itu, penggunaan model pengajaran ini dalam program pendidikan praktis bagi guru dalam pembelajaran umum telah tersebar di universitasuniversitas Amerika, kemudian digunakan di beberapa universitas di Eropa, khusus di antaranya adalah Inggris pada awal tahun 1970-an, sehingga muncu model dan bentuk baru, bahkan universitas-universitas Inggris menetapkan pengajaran mikro sebagai bagian mendasar dalam proses mempersiapkan guru-guru (Perrot, 1977).
Model pengajaran mikro dilaksanakan atas dasar pendekatan behaviorisme dalam belajar melalui perubahan tingkah laku, sebagaimana menurut tokoh pembelajaran terprogram B. F Skinner, yang menguatkan pentingnya umpan balik (feedback) dan penguatan langsung (immediate reinforcement) dalam perubahan tingkah laku. Oleh karena itu, guru yang sedang berlatih menjaga perilaku yang benar, ketika menerima tanggapan positif dari dosennya atau dari audience, dan menjauhi perilaku yang salah ketika ada tanggapan negatif dan dia harus memperbaiki penampilannya secara berangsur-angsur sampai pada penampilan yang diinginkan. Agar guru yang berlatih mendapatkan manfaat dari feedback dan tanggapan untuk memperbaiki penampilannya, seharusnya keterampilan yang dilatihkan itu sependek mungkin. Dari sini, muncul pemikiran untuk membagi pelajaran menjadi beberapa bagian, kemudian membagi setiap bagian menjadi beberapa keterampilan singkat, mungkin guru berlatih berkalikali sampai betul-betul sempurna keahliannya (Stoddart, 1981: 15).

Tahun 1971, pengajaran mikro mulai dikembangkan di negara-negara Asia terutama Malaysia, Pilipina dan kemudian Indonesia. Hal ini didasarkan pada suatu rekomendasi "The Second Sub-Regional Workshop on Teacher Education" (Rohani, 1995: 216). Semenjak akhir tahun 1980-an dan awal tahun 1990-an mulai muncul pengajaran mikro baru, tetapi bukan dengan pendekatan behaviorisme tradisional seperti yang ada pada 1960-an dan 70-an.

\section{KETERAMPILAN-KETERAMPIL- AN DASAR MENGAJAR (TEACH- ING SKILLS) YANG DILATIHKAN DALAM PENGAJARAN MIKRO}

Keterampilan mengajar penting bagi seorang guru agar ia menjadi guru yang profesional, karena di samping 
harus menguasai substansi bidang studi yang akan diajarkan, keterampilan dasar mengajar juga merupakan keterampilan penunjang untuk keberhasilannya dalam proses pengajaran.

Keterampilan mengajar, seperti telah dikemukakan di atas dapat dilatih secara terisolasi melalui pengajaran mikro. Karena situasi belajar mengajar itu sengaja di desain sedemikian rupa sehingga dapat dikontrol, maka pembentukan keterampilan baru ataupun pembaharuan sesuatu keterampilan mengajar dapat dilakukan secara terisolasi. Sebagai cara latihan praktik mengajar dalam situasi laboratoris, maka melalui pengajaran mikro calon guru dapat berlatih berbagai keterampilan mengajar (teaching skilsl) dalam keadaan terkontrol untuk meningkatkan kompetensinya, tetapi pada akhirnya harus dilatihkan penggunaannya secara terintegrasi dalam kegiatan pengajaran di kelas. Oleh karena itu, latihan keterampilan mengajar melalui pengajaran mikro hanya merupakan bagian dari latihan praktik mengajar.

Allen dan Ryan (dalam Rohani, 1999: 218) mengemukakan 14 komponen keterampilan mengajar berkaitan dengan praktik pengajaran mikro, yaitu:

1. Stimulus Variation

2. Set Induction

3. Closure

4. Silence and Non Verbal Cues

5. Reinforcement of Student Partisipation

6. Fluency in asking Questions

7. Probing questions

8. Higher order questions

9. Divergent questions

10. Recognizing attending behavior

11. Illustrating and use of example

12. Lecturing

13. Planned repetition

14. Completeness of communication

Sementara itu, Usman (2003) mengemukakan 7 keterampilan mengajar (teaching skills) yang dapat dilatihkan dalam pengajaran mikro dan harus dikuasai sebelum calon guru melaksanakan praktik pengalaman lapangan di lembaga-lembaga pendidikan. Keterampilan dasar mengajar tersebut adalah:

1. Keterampilan bertanya

Dalam kegiatan belajar-mengajar, bertanya berperan penting karena pertanyaan yang tersusun dengan baik dan teknik pelontaran yang tepat juga akan memberikan dampak positif terhadap siswa. Keterampilan dan kelancaran bertanya calon guru perlu dilatih dan ditingkatkan, baik isi pertanyaannya maupun teknik bertanya.

2. Keterampilan memberi penguatan Penguatan (reinforcement) adalah segala bentuk respons, apakah bersifat verbal ataupun non-verbal, yang merupakan bagian dari modifikasi tingkah laku guru terhadap tingkah laku siswa, yang bertujuan untuk memberikan informasi atau umpan balik (feedback) bagi sipenerima (siswa) atas perbuatannya sebagai suatu tindak dorongan ataupun koreksi. Atau, pengautan adalah respons terhadap suatu tingkah laku yang dapat meningkatkan kemungkinan berulangnya kembali tingkah laku tersebut. Tindakan tersebut dimaksudkan untuk mengganjar atau membesarkan hati siswa agar mereka lebih giat berpartisipasi dalam interaksi belajarmengajar.

3. Keterampilan mengadakan variasi variasi stimulus adalah suatu kegiatan guru dalam konteks proses interaksi belajar-mengajar yang ditujukan untuk mengatasi kebosanan siswa sehingga dalam situasi belajarmengajar, siswa senantiasa menunjukkan ketekunan, antusiasme, serta penuh partisipasi, sehingga sebagai calon guru harus melatih diri agar menguasai keterampilan tersebut. 
4. Keterampilan menjelaskan

keterampilan menjelaskan dalam pengajaran adalah penyajian informasi secara lisan yang diorganisasi secara sistematik untuk menunjukkan adanya hubungan yang satu dengan yang lainnya, misalnya antara sebab dan akibat, definisi dengan contoh atau dengan sesuatu yang belum diketahui. Penyampain informasi yang terencana dengan baik dan disajikan dengan urutan yang cocok merupakan ciri utama kegiatan menjelaskan. Pemberian penjelasan merupakan salah satu aspek yang amat penting dari kegiatan guru dalam interaksinya dengan siswa di dalam kelas. Dan biasanya guru cenderung lebih mendominasi pembicaraan dan mempunyai pengaruh langsung, misalnya dalam memberi fakta, ide, ataupun pendapat. Oleh sebab itu, hal ini haruslah dibenahi untuk ditingkatkan keefektifannya agar tercapai hasil yang optimal dari penjelasan dan pembicaraan guru tersebut sehingga bermakna bagi siswa.

5. Keterampilan membuka dan menutup pelajaran

yang dimaksud dengan set induction ialah usaha atau kegiatan yang dilakukan oleh guru dalam kegiatan belajar-mengajar untuk menciptakan prokondisi bagi siswa agar mental maupun perhatian terpusat pada apa yang akan dipelajarinya sehingga usaha tersebut akan memberikan efek yang positif terhadap kegiatan belajar. Dengan kata lain, kegiatan yang dilakukan oleh guru untuk menciptakan suasana siap mental dan menimbulkan perhatian siswa agar terpusat pada hal-hal yang akan dipelajarinya. Kegiatan membuka pelajaran tidak hanya dilakukan oleh guru pada awal jam pelajaran, tetapi juga pada awal setiap penggal kegiatan inti pelajaran yang diberikan selama jam pelajaran itu. Hal tersebut dapat dilakukan dengan cara mengemukakan tujuan yang akan dicapai, menarik perhatian siswa, memberi acuan, dan membuat kaitan antara materi pelajaran yang telah dikuasai oleh siswa dengan bahan yang akan dipelajarinya.

Sedangkan menutup pelajaran (closure) ialah kegiatan yang dilakukan oleh guru untuk mengakhiri pelajaran atau kegiatan belajar-mengajar. Usaha menutup pelajaran itu dimaksudkan untuk memberi gambaran menyeluruh tentang apa yang telah dipelajari oleh siswa, mengetahui tingkat pencapaian siswa dan tingkat keberhasilan guru dalam proses belajar-mengajar.

6. Keterampilan mengelola kelas

Pengelolaan kelas adalah keterampilan guru unutk menciptakan dan memelihara kondisi belajar yang optimal dan mengembalikannya bila terjadi gangguan dalam proses belajar mengajar. Dengan kata lain kegiatan-kegiatan untuk menciptakan dan mempertahankan kondisi yang optimal bagi terjadinya proses belajar mengajar. Yang termasuk ke dalam hal ini misalnya penghentian tingkah laku siswa yang menyelewengkan perhatian kelas, pemberian ganjaran bagi ketepatan waktu penyelesaian tugas oleh siswa, atau penetapan norma kelompok yang produktif.

Suatu kondisi belajar yang optimal dapat tercapai jika guru mampu mengatur siswa dan pengajaran serta mengendalikannya dalam suasana yang menyenangkan untuk mencapai tujuan pengajaran juga hubungan interpersonal yang baik antara guru dengan siswa dan antara siswa dengan siswa merupakan syarat keberhasilan pengelolaan kelas. Pengelolaan kelas yang efektif merupakan prasyarat mutlak bagi terjadinya proses belajar mengajar yang efektif. 
7. Keterampilan menggunakan media Dalam proses belajar mengajar kehadiran media mempunyai arti yang cukup penting. Karena dalam kegiatan tersebut ketidakjelasan bahan yang disampaikan dapat dibantu dengan menghadirkan media sebagai perantara. Kerumitan bahan akan disampaikan kepada anak didik dapat disederhanakan dengan bantuan media. Media dapat mewakili apa yang kurang mampu guru ucapkan melalui katakata atau kalimat tertentu. Bahkan keabstrakan bahan dapat dikonkritkan dengan kehadiran media. Dengan demikian, anak didik lebih mudah mencerna bahan dari pada tanpa bantuan media.

Djamarah (2002: 137) menjelaskan bahwa peranan media tidak akan terlihat bila penggunaannya tidak sejalan dengan isi dari tujuan pengajaran yang telah dirumuskan. Karena itu, tujuan pengajaran harus dijadikan sebagai pangkal acuan untuk menggunakan media. Manakala diabaikan, maka media bukan lagi sebagai alat bantu pengajaran, tetapi sebagai penghambat dalam pencapaian tujuan secara efektif dan efisien. Akhirnya, dapat dipahami bahwa media adalah alat bantu apa saja yang dapat dijadikan sebagai penyalur pesan guna mencapai tujuan pengajaran.

\section{MACAM-MACAM PENGAJARAN MIKRO}

Pengajaran mikro berbeda-beda sesuai dengan program yang dilaksanakan, tujuan latihan yang ingin dicapai, keterampilan yang dilatihkan, level peserta latihan. Stoddart (1981: 13) mengemukakan beberapa bentuk pengajaran mikro:

1. Preservice training in microteaching, yaitu pengajaran mikro yang dilaksanakan ketika mahasiswa dalam perkuliahan, artinya sebelum mahasiswa menyelesaikan pendidikannya dan melaksanakan tugas mengajar di lapangan.

2. In-service training in microteaching. Jenis ini meliputi guru-guru yang melaksanakan pengajaran dan pada waktu yang sama ia menyampaikan pelajaran sambil melatihkan satu keterampilan tertentu yang belum ia latihkan sebelumnya, dengan cara ini.

3. Continuous microteaching, yaitu pengajaran mikro yang dilaksanakan secara terus-menerus dari awal dan berlanjut terus sampai mahasiswa tamat.

4. Final microteaching, yaitu pengajaran mikro yang dilaksanakan oleh praktikan pada tahun akhir pendidikannya.

5. Directed microteaching, yaitu mencakup beberapa tipe pengajaran mikro terbimbing seperti modeled microteaching dimana dosen pembimbing menyajikan suatu model pengajaran mikro kepada mahasiswa calon guru kemudian mahasiswa dituntut untuk mencontoh atau mempraktikkan model tersebut dihadapannya.

Di samping beberapa bentuk di atas, masih terdapat beberapa bentuk pengajaran mikro yang lain seperti undirected microteaching (lawan dari directed microteaching), general microteaching, specific microteaching dan sebagainya. Namun diantara beberapa bentuk pengajaran mikro di atas terdapat overlapping dalam hal pendekatan, tujuan dan pelaksanaaannya. Sehingga secara umum pengajaran mikro tersebut dapat dibagi pada dua bagian, yaitu: pengajaran mikro umum untuk melatihkan keterampilan-keterampilan umum mengajar, dan pengajaran mikro khusus untuk melatihkan keterampilan-keterampilan khusus dalam lapangan tertentu seperti pengajaran bahasa asing. 


\section{KELEBIHAN MICROTECHING DAN MANFAAT-MANFAATNYA}

Pengajaran mikro adalah pengajaran terapan yang sebenarnya, yang tidak berbeda jauh dari latihan pengajaran yang komplek, dimana mencakup semua unsur pengajaran yang ada, seperti guru, siswa ataupun yang berperan sebagai siswa, pembimbing, keterampilan mengajar, media pengajaran, feedback dan penguatan/tanggapan, serta evaluasi. Apabila beberapa tujuan dibuat, maka berarti di dalamnya ada beberapa kelebihan yang tidak terdapat dalam berbagai macam pengajaran yang biasa lainnya, seperti feedback (umpan balik), penguatan segera, kritikan yang membangun, berganti peran dan lainlain.

Pengajaran mikro memiliki beberapa kelebihan dan kegunaan, bukan hanya pada latihan mengajar tetapi juga pada lapangan belajar mengajar lainnya, seperti latihan mempersiapkan materi ajar, latihan mengevaluasi kegiatan guru dan murid, melaksanakan penelitian aplikasi, dan berikut ini beberapa kelebihan pengajaran mikro dan manfat-manfaatnya dalam program pengajaran:

1. Menyelesaikan masalah yang dihadapi pelaksana program persiapan guru, seperti banyaknya guru yang akan berlaatih atau kurangnya pembimbing, atau tidak tersedianya kelas yang sebenarnya, atau sulitnya menyepakati antara waktu belajar dan waktu latihan, atau luputnya materi yang harus dilatihkan dari program pengajaran

2. Menghemat waktu dan tenaga, dimana dalam pengajaran mikro memungkinkan melatih guru untuk beberapa keterampilan yang penting dalam waktu singkat, tanpa menyianyiakan waktu dan tenaga untuk melatih keterampilan yang telah dikuasai guru sebelumnya, sebagaimana juga pengajaran mikro meminimalisir kebutuhan untuk melatih setiap guru yang berlatih terhadap semua keterampilan, karena melihat dan berdiskusi akan memberikan manfaat bagi yang melihat sebagaimana manfaat bagi yang berlatih.

3. Melatih guru dengan sejumlah keterampilan mengajar yang penting, seperti kecermatan dalam menyajikan dan mengajarkan, mengatur waktu dan memanfaatkannya, mengikuti langkah-langkah yang telah dituliskan dalam RPP serta memanfaatkan teknologi pengajaran dengan cara terstruktur dan teratur disamping menggunakan gerakan tubuh dalam mengajar.

4. Melatih guru mempersiapkan dan menyusun materi pelajaran, karena biasanya untuk microteaching materi yang disajikan adalah materi baru yang dipersiapkan oleh guru yang berlatih itu sendiri atau menyimpang dari materi yang ada untuk menyesuaikan antara keterampilan dengan waktu yang tersedia

5. Diskusi guru yang berlatih langsung setelah selesai microteching, dan memungkinkan dosen pembimbing masuk di tengah-tengah pengajaran dan mengulang pengajaran, khususnya ketika mengajar teman-teman guru tersebut sebagai (siswanya). Inilah masalah yang sulit menerapkannya dalam pengajaran yang komplek, khususnya dalam kelas yang sebenarnya .

6. Pengajaran mikro yang mendasarkan pada pemecahan keterampilan-keterampilan menjadi beberapa bagian keterampilan, merupakan hal yang membantu untuk menjaga perbedaan kepribadian antara guru-guru, melalui melatih mereka dengan sejumlah keterampilan yang dilalaikan oleh program latihan pengajaran secara komplek 
7. Menyediakan waktu bagi guru yang berlatih untuk mengetahui kekurangan dan kelebihannya dari aspek keilmuan, amaliah dan seni, melalui apa yang disampaikan berupa feedback dan penguatan dari dosen pembimbing dan teman-teman dalam bentuk kritikan, yang mana memberikan waktu baginya untuk memperbaiki perilakunya dan perkembangannya sebelum masuk lapangan pengajaran dimana tidak ada lagi kritikan, tidak ada feedback, dan tidak ada penguatan, yang mana hal itu membantunya untuk mengevaluasi diri melalui melihat sendiri di kaset video

8. Memberikan kesempatan bagi guru untuk bertukar peran antara mereka, dan mengidentifikasi masalah-masalah pengajaran dari jarak dekat, yaitu masalah guru, sisiwa dan itu melalui duduk di bangku belajar, dan berperan dengan karakter siswa yang sedang belajar, dan mendengarkan guru, berinteraksi dengannya, kemudian memainkan peran guru dan seterusnya (situasi ini khusus bagi pengajaran sesama teman)

9. Mengkorelasikan antara teori dan aplikasi, dimana memungkinkan menerapkan teori atau aliran atau metode manapun secara aplikatif praktis dalam ruang belajar, ketika sedang men-

\section{DAFTAR RUJUKAN}

Abdullah Umar al-Fara dan Abdurrahman Abdusssalam Jamil. 1999. al-Mursyid al-Hadits fi alTarbiyah al-Amaliyah wa alTadris al-Mushaghghar, Oman: Maktabah DarTsaqafah li al-Nasyr wa al-Tauzi'.

Brumfit, C. J. 1979. A Sevenday Microteaching Programme for EFL Teachers, London: University of London, jelaskan atau setelahnya, apabila perlu.

\section{PENUTUP}

Berdasarkan percobaan lapangan dan kajian teoritis, maka diketahui bahwa pengajaran mikro adalah cara terbaik untuk menyelesaikan masalah dalam pengajaran. Pembahasan ini penting bagi semua praktisi pendidikan, dosen, guru dan guru yang berlatih (calon guru), karena manfaat yang diperoleh, serta efisien dan efektif yang tinggi dalam rangka melatih keterampilan mengajar yang relevan dengan profesi keguruan. Pengajaran mikro dalam rangka praktek kependidikan, telah di gunakan oleh LPTK/Biro Praktek keguruan untuk mempersiapkan dan memperbaiki penampilan mengajar mahasiswanya. Pengajaran mikro berfungsi sebagai alat pembantu atau prasyarat dari program praktek pengalaman lapangan, dengan kata lain latihan praktek tidak berhenti sampai dikuasainya komponen-koponen keterampilan mengajar di dalam pengaruh mikro, tetapi perlu diteruskan sehingga calon baru dapat mempraktekkan kemampuan mengajarnya secara komprehensif dalam real class sehingga dapat terbina performance seorang guru sebagaimana yang diharapkan.

Cassel, Jeanne dan Blake, Frances. 1988. Microteaching with a Multicultural Focus. The Educational Resources Information Center (ERIC),

Djamarah, Syaiful Bahri dan Zain. 2002. Aswan, Strategi Belajar Mengajar, Jakarta: PT Rineka Cipta,

Hasibuan, J.J. dan Moedjiono. 1999. Proses Belajar Mengajar, Bandung: PT Remaja Rosdakarya, 
Perrot, E. 1977. Microteaching in Higher Education: A Society for Research into Higher education,

Rohani, Ahmad dan Ahmadi. 1995. Abu, Pengelolaan Pengajaran, Jakarta: PT Rineka Cipta.

Stoddart, John Dennis. 1981. Microteaching: Current Practice in
Britain, London: London University

Usman, Moh. Uzer. 2003. Menjadi Guru Profesional, Bandung: PT Remaja Rosdakarya.

Wallace, Michael. 1991. Training Foreign Language Teachers: a Reflective Approach, Cambridge: Cambridge University Press, 